Open Access

\title{
"Selective firming" of the self-boundary: social movements and the reshaping of the state-individual relationship during China's transformation: A case study of a collective litigation caused by demolition in City B
}

Yunqing Shi

Correspondence: shiyq@cass.org.cn
Institute of Sociology, Chinese
Academy of Social Sciences, No,5,
Jianguomennei Dajie, Beijing, China

\begin{abstract}
Urbanization since the 1990s causes considerable social conflicts in China. From a positive perspective, the conflicts can be regarded as an active reshaping of state-individual relationships initiated by the actors through social movements. However, due to the specific political condition as protests are not institutionalized in China, actors here face a dilemma: they must produce both the "legitimacy" to protest and the "opportunity" for protest at the same time during their rights-defending movements. This implies a paradox as far as state-individual relationships is considered. To get the "opportunity", actors have to detach themselves from the state which they are supposed to be subordinated to; meanwhile, to secure the "legitimacy", they have to internalize the state as it used to be. Therefore, tensions exist between these two kinds of state-individual relationship caused by the dilemma. To deal with this dilemma, actors in this case have to conceptualize the state as two levels: the abstract central government and concrete local governments. An adaptive mechanism, referred to as the "selective firming mechanism of the self-boundary" in this article, is developed to construct different state-individual relationships when dealing with different state levels. Therefore, by examining a collective litigation caused by demolition in City B, this mechanism of "selective firming" can be understood in three steps: firstly, actors distinguish the concrete state from the abstract state, so as to build respective relationships with the different levels of state; secondly, they distinguish the land-use rights from the land ownership when considering the abstract state; thirdly, they distinguish the economic function from the political and administrative duties when considering the concrete state. Through this triple-level distinction, actors successfully restrict the effect of the subordinate state-individual relationship resulted from the Chinese tradition, while expanding the space for an emerging egalitarian relationship between the individual and state responding to the changing society. The nature of this mechanism is the transformation of the self-boundary from being flexible and permeated to being fixed and firm. During this process, the relationship between individuals and state is reconstructed, whilst a modern state is built out of a unified, traditional state.
\end{abstract}

Keywords: Self-boundary; Selective firming; State-individual relationships; Social movements

\section{Springer}

(c) 2015 Yunqing. This is an Open Access article distributed under the terms of the Creative Commons Attribution License (http:// creativecommons.org/licenses/by/4.0), which permits unrestricted use, distribution, and reproduction in any medium, provided the original work is properly credited. 


\section{Background}

In the 1990s City B experienced the first massive wave of urbanization. According to the "Yearbook of Real Estate of City B," the total size of the relocated population between 1991 and 2000 was 281,200 households, or 878,600 person; 647,800 houses that occupied 9,155,300 square meters were demolished. The main pattern of urbanization in this stage was " combining dilapidated house renewal with real estate development" (Kaifa Dai Weigai), demonstrating the birth of the real estate market under the dominance of state. At this stage, under the banner of urbanization, modernization, and economic development, land and space were commercialized under the collaboration of capital and political power (Burawoy 2000, 2006; Shen, 2007: 282, 353), which created the miracle of the Chinese economy. However, on the other side of the coin, as the danwei (work unit) system broke down during the reform, people involved in the "dilapidated house renewal" were atomized individuals without effective social associations. Psychologically shaped by thousands of years of cultural tradition and the political regime, these people were still unconditionally obedient to authority. Therefore, personal rights were seriously infringed not only by the capital supported by state power, but also by their obedience to the authority carrying on from the traditional state-individual relationship. A series of large-scale public protests were triggered, which attracted extensive public attention as well as stimulating a large number of empirical studies. Under this background, this collective litigation involving 10,357 people provided a typical case for examining the transformation of relationships between the state and individuals in contemporary China.

\section{The Dilemma of social movements}

Considering contentious politics in the Chinese context, where it differs from the western experience is the high pressure put on the actors from the state. Thus, whether the protest will make a challenge to the political system becomes a critical question. As many previous studies have touched upon the fundamental legitimacy problem of rights defending $^{1}$ (Weiquan) action under China's political system (see Bi 2006; Ying 2007), which suggested the lawful resistance as a key point (O'Brien and Li 2006), this article further examines the function of discourses on rights in law: Does the employment of legal discourses that indigenously developed within the framework of the state and the understanding of rights in China's context challenge or paradoxically strengthen the authority of the Chinese state?

Western academia tends to be more optimistic about the challenging potential of the "rights-defending" actions. They believe that the observed rights discourses from recent protests marked a bottom-up demand for civil rights in China, and constituted a fundamental breakthrough in the traditional subordinate state-individual relationships. Thus, these protests posed a potential threat to the regime (see Goldman 2005; O'Brien and Li 2006). However, Perry (2008) believes that the essence of people's demands for socioeconomic justice was appealing to the right to survival. Such moral and economic claim rarely questioned the legitimacy of the Chinese Communist Party (CCP) and its ideology. Therefore the protests essentially reinforced, rather than eroded, the political system. In fact, findings show that these two diametrically opposed interpretations are not in an either-or situation, but in a coexisting situation full of 
tensions, respectively leading to the actors' considerations of effectiveness and legitimacy during their rights defending movement. For example, Liu (2010) revealed a dual attribute of laws-a "weapon for rights defending" and an "institutional bottleneck"-through the interpretation of diversified trajectories of real estate owners' rights defending action. This reflects the peculiar dilemma of the current Chinese social movement for civil rights: China's rights defenders must continually confirm the legitimacy of their rights defending behavior while creating protest opportunities for their actions; the latter constitutes challenges to state authority while the former intentionally or unintentionally internalizes the state authority to a certain extent.

Although this dilemma has been noted by many researchers, it was treated no more than strategies of rights defending in China's context. For instance, by studying people protesting at government agencies, Ying Xing and his colleagues described the strategy for handling this dilemma by "stepping on lines instead of crossing borders" (Caixian er bu Yuejie) (Ying and Jin 2000). This article,however attempts to show that this is not only a strategy demonstrated in ordinary people's daily wisdom, but also constitutes a basic logic of social transformation at an individual level. Its essence is the selective construction of the state-individual relationship according to specific contexts, which is worth exploring.

\section{The state-individual relationship and the self-boundary of Chinese people}

The subject of the individual has long been an overlooked analytical dimension in sociological research due to the restrictions of sociological paradigms. In recent years, emphasizing the transformation process and peculiar institutional context, many social movement studies cited the standpoint of sociology of action and focused on actors and the processes of their practices. The basic question to be answered here is how a society is produced under the framework of the state-society relationship (Shen 2007). The introduction of the social psychology perspective expands the study of social transformation from a macro-social structural level to a micro-individual level, which further extends the question of "how society could be produced" to the discussion of "how citizens could be produced", especially in the Chinese context. Thus the state-individual relationship is introduced in this research, employing the self-construal of Chinese individuals as a key tool for analysis.

From an indigenous psychological perspective, the state and individuals are associated via two paths in the Chinese traditional culture: one from the bottom up, from inside to outside, through "Cultivating Self, Putting Family in Order, Governing State, and Pacifyiing the World" (Xiushen,Qijia, Zhiguo, Pingtianxia); the other from the top down, from outside to inside, namely through the state's moral requirements of individuals, requesting their obedience to state instructions and their faith in their country represented by the Chinese empires. These push-and-pull forces enable a mutually inclusive and unified relationship between the state and individuals (Yang 2008). The basis of this relationship is the Chinese people's boundary-permeated self formed under the differential mode of associations (Chaxu Geju). Its most remarkable characteristic is the elasticity, flexibility, and permeability of the boundary of the self. In other words, individuals can adjust their state-individual relationships to different social situations by adjusting their self-boundary ${ }^{2}$. 
Therefore, by adopting the perspective of the state-individual relationships, this work extends the concept of social structure with historical and cultural conditions at a broader level. Firstly, compared to the prevalent analytical frame of state-society relationships, state-individual relationships better fit the Chinese context, since "society" is missing in traditional Confucian culture (Yang 2008). Secondly, state-individual relationships are also in transition accompanied by social changes; combined with the "subjectivity of actors" emphasized in sociology of action (Touraine 2008), social movements can be regarded as the struggle initiated by actors to reshape the traditionally subordinate stateindividual relationships. Subjectivity, then, appears in the reconstruction of one's self-construal through practices of rights defending (highlighted in this article as the firming mechanism of one's self-boundary). Moreover, by adopting state-individual relationships as the analytical core, transformation can be considered as a process of improvement from a totalitarian ${ }^{3}$ state to a modern state with four differentiated parts-state, market, society, and individuals (Yang 2008). Through remodeling their self-construal, individuals aim to directly or indirectly reshape the state-individual relationships, which rematches the deep cultural-psycho structures with the changing social structures. From this standpoint, the social conflicts that occur during urbanization result from interactions between these four differentiated parts, making them the lens to observe the transformation of the state-individual relationships in China.

\section{Rights in Chinese-style and citizens in production}

To understand the prevalence of "rights discourses" in the current rights defending movement, many studies have noted that the Chinese people's philosophy of rights is essentially different from the natural rights ascribed to God in the Western world. The Chinese people generally understand rights as measures approved by the government that promote national unity and prosperity, whereas Western people regard rights as a protective mechanism against interventions from the state (Perry, Elizabeth 2008; Yan 2011; Zhuang 2011). This discrepancy derives from the different state-individual relationships in China and in the Western world. In other words, the Chinese state-individual relationships take the totalitarian state as its starting point and end with the state's protective functions for individuals, while those in the West adopt the independent individual as their starting point and end with the constraints on state power.

Faced with the dilemma during the current rights defending movement mentioned above, actors respond with the following basic logic: they take traditional subordinate state-individual as an ideological repository to borrowing authority from the state to produce legitimacy for their rights defending; at the same time, they take modern egalitarian state-individual relationships as a weapon to explore opportunities for their protest and construct a new sense of civil rights. The traditional type has a deep historical and cultural root that internalizes the state in individuals; while the latter is a state of emergence and detaches individuals from the state. Therefore, the actions of rights defending become a practical process for understanding these two opposing state-individual relationships. For actors, achieving an appropriate balance between them is the key to the success of their rights defending.

This article thus emphasizes that both the production of society and the production of citizens are embedded in certain social and historical conditions. The former 
involves the birth of society under a totalitarian state background where society was in absence. The latter involves the germination of citizens in the Western style, as individuals trying to restrict state power, within the paternalistic Chinese tradition in which the state is considered as the provider of protection for people and the guardian of their well-being. Therefore the analyses in this study integrate cases of social movements during the process of urbanization, taking the state-society relationship as the starting point, and utilizing the analytical tool of "self-boundary" from a social psychology perspective. The specific questions to be answered are: Can the traditional Chinese boundary-permeated self change? If so, how will it change? How will its changes reshape the state-individual relationships?

The remainder of this paper is organized as follows: Part II introduces the cases and methods; Part III explains the ideal types of subordinate and egalitarian state-individual relationships and their symbiosis as well as entanglement in the current situation; Part IV introduces the concept of the self-boundary and analyzes the selective firming mechanism. The detailed process of selectively constructed state-individual relationships in order to cope with the dilemma in the current social movement is then discussed. The conclusion reviews the entire paper and further discusses the connections between the micro-transformation of individuals' self-boundary during the social movement and the simultaneous macro-social transformation.

\section{Methods}

On February 22, 2000, seven representatives of citizens led by Mr. Luo submitted to the Second Intermediate People's Court of City B an administrative proceeding with 10,357 plaintiffs, suing the Municipal Housing and Land Administration Bureau of municipal B's government. This was the once-sensational event called the "Grand Litigation of Ten Thousand Plaintiffs" (hereafter "Grand Litigation"). This Grand Litigation, which began in 1995 and continues till today, can be roughly divided into three stages-the preparation stage (1995-1999), the implementation stage (1999-2001), and the impeachment and continuation stage (2001-present) (see the case details in Shi 2007, Shi 2012). The main force behind this litigation was residents relocated during the period of "combining dilapidated house renewal with real estate development" in City B before 1998. In a 2006 questionnaire survey $(\mathrm{N}=454)$ of those residents, the average age of the respondents was 55.58 years old; 46.3 percent of the sample was male. Retired residents made up the largest portion (47.1 percent), followed by workers (24.7 percent) and laid-off workers (15.0 percent). The politically unaffiliated accounted for 46.7 percent, while CCP members accounted for 7.3 percent. Those working in state-owned enterprises composed 50.4 percent, followed by those who had retired from state-owned enterprises (15.6 percent), then those in collectively owned organizations (13.2 percent) and unemployed (7.3 percent). Those who reported that their demolished houses were private accounted for 28.9 percent with an average size of houses and courtyard areas of 110.91 square meters; $69.2 \%$ reported that they resided in public housing with an average housing area of 21.93 square meters (few public housing residences had courtyards). As data from interviewees showed, during the period of impeachment and continuation since 2001, participants in this litigation also included landless peasants and urban residents newly relocated after 1998 ; the number of people in litigation varied from 5,216 to 22,304 . 
Among the collective actions caused by inner-city demolition, this was the first case asserting the actors' entitlement to property rights and citizenship instead of cash or housing. Its enormous scale, long duration, and participants' rigorous actions make it the most rational end of "the pedigree of urban movement" (Bi 2006). It could also be called a " civic movement." From the perspective of this work, the case comprises the tripartite forces of the state, market, and society in the context of social transformation. It also reflects transcendence over the Chinese-style rights in the details of group and individual actions. A claim of property rights that is closer to the Western context has quietly burgeoned, indicating the firming tendency of the traditionally permeated boundary of self. This provides a unique perspective for exploring the transition of the state-individual relationships during the vicissitude of the Chinese society.

With regard to research methods, this study mainly adopted interviews of individuals and focus groups as well as supplementary semi-open public forums and questionnaire surveys. The survey focuses on a variety of text materials, including assemblies of cases, letters on impeachment, submissions, and others. The changes within the litigation group, such as flows of members and changes of the cultural framework, were also analyzed. Moreover, close attention was paid to the grasping of political opportunities and the use of resources for moblization, particularly the actions of litigation groups before and after sensitive time points such as the plenary sessions of the National People's Congress. This study places the actors in a real laboratory of the social field and overcame the problem of ideality of experimental conditions in psychological studies, consequently providing a relatively unique perspective.

\section{Results}

\section{Models of state-individual relationships and their practices}

\section{State-individual relationships in two ideal types}

If we look back into the Chinese history, a modern individual was virtually nonexistent until the opening up in the 1980s. Fei Xiaotong distinguishes the basic social structures of China and the Western world through the theoretical models of "the differential mode of associations" (Chaxu Geju) and "the group mode of associations" (Tuanti Geju). Based on this distinction, indigenous psychology distinguishes two different patterns of self-construal and their corresponding individualisms, which this article extends to two ideal types of state-individual relationships (as shown in Table 1). The main difference between the "ensemble individualism" and the "self-contained individualism" (Sampson 1988) ${ }^{4}$ lies in the state of their boundaries-whether it is fluid and ambiguous, or firm and clear. The "ensemble individualism" is mostly illustrated by dashed lines, emphasizing the permeability and flexibility of the self-boundary. As an agent, an individual

Table 1 Self-construal and state-individual relationships under two modes of social association

\begin{tabular}{|c|c|c|c|}
\hline Social structure & $\begin{array}{l}\text { Characteristics of } \\
\text { individualism }\end{array}$ & $\begin{array}{l}\text { Characteristics of } \\
\text { self-boundary }\end{array}$ & State-individual relationship \\
\hline $\begin{array}{l}\text { Differential mode of associations } \\
\text { in China }\end{array}$ & $\begin{array}{l}\text { Ensemble } \\
\text { individualism }\end{array}$ & $\begin{array}{l}\text { Permeability: elasticity } \\
\text { and flexibility }\end{array}$ & $\begin{array}{l}\text { Individual absorbed by the state } \\
\text { and subordinate to the state }\end{array}$ \\
\hline $\begin{array}{l}\text { Group mode of associations in } \\
\text { the West }\end{array}$ & $\begin{array}{l}\text { Self-contained } \\
\text { individualism }\end{array}$ & $\begin{array}{l}\text { Firming: closed } \\
\text { and fixed }\end{array}$ & $\begin{array}{l}\text { Individual independent from the } \\
\text { state and equal with the state }\end{array}$ \\
\hline
\end{tabular}


can contain others, such as his/her family, friends, neighbors, and, ultimately, the state and even the world by expanding his/her self-boundary to the corresponding level in different situations. Indeed, Confucius's teaching in Chinese culture points out that the more expansive the self is, the more superior the individual is by moral standards. In short, the boundary-permeated self-construal addresses the dynamic of inclusion and exclusion, and the hierarchical structure indicating the moral level (see more on the boundary-permeated self in Yang et al. 2010). Regarding the state-individual relations based on the self-construal, when individuals show their obedience to the state, they made it through expanding their self-boundary to contain the state as a part of their appraisal of "me" (the national self) and they will also be morally praised in this process. This moral implication subsequently helps to form a subordinate relationship between individuals and the state. On the contrary, the "self-contained individualism" is illustrated by solid lines, emphasizing that the self-boundary is firm and closed. Accordingly, the state is only regarded as one of many associations that comprise individuals. Thus individuals are independent from the state and build an egalitarian relationship with the state.

From the perspective of the state-individual relationships, social changes since the founding of the People's Republic of China can be regarded as a process of social individualization (Yan 2012) that implies a reconstruction of individuals' self-boundary. This process includes two stages. During the three decades before the reform (1949-1979), the social transformation launched by the state pulled individuals out of their families and kinship relations. It further made individuals as the main body of socialism and then embedded them into a state-controlled redistributive system in work and life. "Partial individualization" was realized (Yan 2012, 353-58). However, the usurpation of families by danwei (work unit) did not substantially alter the self-construal of individuals. The boundary-permeated self was retained and individuals were still engulfed and absorbed by the state. During the recent period since 1979, a market-oriented economic reform has weakened the previous "individualization with collective manners" (Yan 2012, 376), bringing about substantial changes-full of controversies and conflicts-to the state-individual relationships and the individuals' self-construal. Since the reform, the state has gradually transited into performance-oriented legitimacy based on market economy. Meanwhile, it continued with the maintenance and construction of socialist ideology. The market economy stimulated the generation of awareness of individual rights, firmed the self-boundary, and initiated social associations among individuals, whereas the socialist ideology still required unconditional obedience of individuals to the state, the permeability of the self-boundary, and an atomized status of individuals. This paradox resulted in deep contradictions during the transformation and also lay the unique background for China's problems.

Essentially, the two phases are both state-controlled processes of individualization that conforms with the traditional definition of individuals, since they are always subordinated to the larger collectivities, such as families, ancestries, or the nation state (Yan 2012, 376). Therefore, from another angle, the massive urban redevelopment of the early 1990s was rooted in a deeper cultural-psycho origin: the boundary-permeated self along with the subordinate state-individual relationship facilitated the continuing alliance of the state and the market, when the society is absence in this especially context. Therefore, from a positive angle, the large number of social conflicts since the early 1990s 
could be considered as an active response from individuals to the traditional pattern of the state-individual relationships. This response is aimed at building a more equal state-individual relationship based on an independent self with firm boundaries cultivated in the market economy, to protect their property and civil rights from the alliance of the power and capital.

These two ideal types of the state-individual relationships both exist in contemporary China, but they are at different levels of development. Immersed in the socialist ideology and thousands of years of cultural heritage, the subordinate state-individual relationship based on the boundary-permeated self are still dominant; inspired by the opening market, the equality-oriented relationship based on the boundary-fixed self is still incipient. In the practice of rights defending, actors constructed different state-individual relationships according to their situations. Those were not only active strategies by individuals, but also revealed a historical and cultural background with various social constraints, which constituted part of a larger social structure.

\section{State-individual relationships in practice}

The state is essentially a network of systems and actors, and practices within the society. Individuals can find different ways to interact with the different levels of state actors and agencies (Pieke 2004). There are various levels of governance in China, of which the central government and local governments are the two most typical layers. As summarized by Cao (2011), the former is characterized by the power to rule officials, whereas the latter is characterized by the power to rule the masses; in Cao's opinion, this separated governing system reduces the risk of governance and contributes to the long-term stability of the Chinese political system. Considering the two coexisting state-individual relationships mentioned above, the key to understanding the actor's view of this multiple-level state is: how do they choose different practical forms-setting their self-boundary as permeated or firm - according to the timing and the level of government with which they are interacting. In other words, how do actors simultaneously produce the legitimacy of their rights defending and opportunities for protest in terms of their selective construction of state-individual relationships?

During the urbanization process since the 1990s, land has become the most important resource in China's sustained economic growth. Land in China has three particular properties. Firstly, under the context of China's official ideology, land is the carrier of the state-the establishment of the CCP as a new regime is inseparable from the socialist reconstruction of land ${ }^{5}$. Secondly, in the context of the market economy, land is equal to the space being commercialized for local accumulation, which serves as the key for local government to obtaining legitimacy from their performance in the economic transition. Thirdly, from a daily-life angle, land encompasses the private livelihood of individuals, which is oppressed by the state and the market. Therefore the commercialization of land and space in the third wave of globalization causes the entanglement of global capital, administrative power at different levels of the state, and individuals' daily life. This has been the source of a large number of social conflicts during the social and economic transition.

During this process, local governments and social actors have different understandings of state-individual relationships. Local governments consider themselves to be the subsidiaries of the state that naturally carry an ideological legitimacy, maintain the previously 
subordinate state-individual relationships, and demand individuals' unconditional obedience. Social actors, through specific applications of law, split the state into two levels-an abstract state embodied in the central government and a concrete state embodied in the local governments. They selectively form alliances with the central government from the ideological aspect, while defining the local government as an executor of concrete policies. Thus, two types of state-individual relationships are created-a subordinate central state-individual relationship, and an equal/independent local state-individual relationship. This split is based on three factors: personal obedience to the central government, personal independence of local governments, and local governments' violation of central government. Thus the legitimacy of rights defending and the opportunities for protest are simultaneously generated. Figure 1 shows the relationships between these three pairings.

\section{The dual role of law- the embodiment of central government guidance vs. texts that stipulate rules}

Consistent with the split of the state into the abstract and concrete levels, laws have also been given a dual role, as the embodiment of central government guidance and the texts that stipulate rules, when help constructing two different state-individual relationships. Regarding laws as the embodiment of central state, actors only selectively refer to the laws legislated by the central government, and by emphasizing the levels of laws, actors addressed the authority of the state rather than looking into the specific contents of legal texts. By adopting such symbolism, actors construct subordinate psycho-connections between them and the abstract state by using their permeated self-boundary. Regarding laws as rules, actors firm their self-boundary and construct independent and equal relationships between them and the local governments. The redefinition of "demolition" has become the logical starting point for reshaping state-individual relationships when it comes to the issue of inner-city reconstruction.

The official discourse of "demolition"-subordinated individuals' obligation to the city development as a common good In the local official discourse, the landuse rights of private housing are administratively allocated by the state, regardless

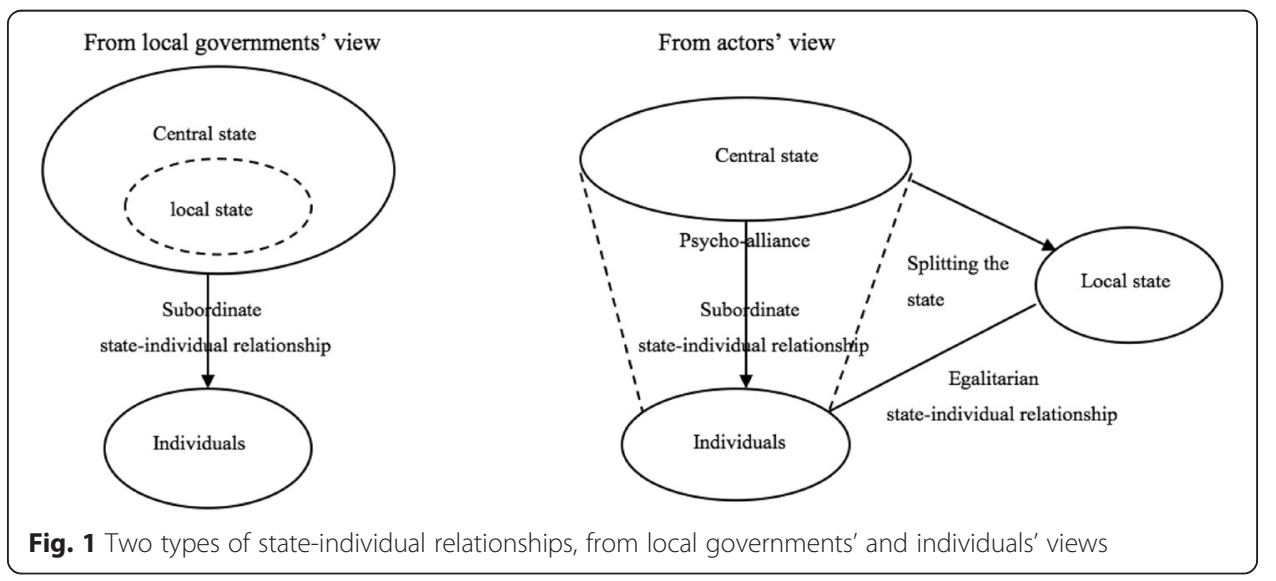


of whether they were obtained privately before the nationalization period in the early days of the establishment of PRC. Under this precondition, demolition has been accordingly operationalized as compensation for the building materials of the demolished houses ${ }^{6}$, which excludes the value of land. Along with the banners of "development," "stability," and others, the local government ideologically inherits the legitimacy of the abstract-sense state by emphasizing the national economic and political importance of inner-city demolition and redevelopment. Within this context, obedience becomes a moral requirement of individuals. This is illustrated by three means: official media manipulated by local governments, administrative documents, and replies to petition letters.

Regarding the land-use rights of urban private housing historically achieved in pre-Revolution era, according to the current law in China, the use rights have been approved by the state. However, these use rights should be defined as achieved through the administrative allocation of state-owned land. Therefore, in the case of urban house demolition, compensation includes the house of the homeowners but excludes the land. The state, as the landowner protected by the laws, can take back the allocated land without paying any compensation. In accordance with the "Regulations of Urban House Demolition Management" by the State Council, only the ownership and the use rights of the house should be compensated ${ }^{7}$.

This year, a few private homeowners whose homes had been demolished proposed that the state should compensate them for their land-use rights of the state-owned land beneath their evicted houses. Vehement opposition and continual petitions to upper-level governments by homeowners resulted in the suspension of some of those demolition projects. It affected the construction and social stability of B City. ("Asking for instruction about the compensation for land-use rights of the state-owned land beneath the demolished urban private housing," The Land and House Bureau of B City [1995] No. 434, July $\left.21^{\text {st }}, 1995\right)$.

To meet the developmental needs of City B, according to "the Law of Land Management" and "the Regulations of Housing Demolition Management," the state can legally reclaim the use rights of state-owned land ("Reply from the general office of people's congress of City B to the open letter from Mr. Luo and the other six citizens about the demand for establishing a special investigation committee," December 15, 2000).

Under the framework of the subordinate rather than equal state-individual relationships, demolition was a coercive governmental behavior from the outset. During the execution of demolition, rights defending behaviors were viewed by some law enforcement officials as confrontational. The "remarks and deeds" session of "The First Open Letter" of the litigation group recorded:

Mr. L, the official of the People's Court of District C of B City, said to Mr. Xu, a relocated resident: "Do you know who I am? You should ask around about what I am doing. Go and ask people around the south part of the city. You have to leave here, whether you want to or not. We prefer the interests of developers. You can petition whomever you know. We will demolish your house even if we are wrong. For you, it does not matter whether it is right or wrong. How can developers gain profits if you do not leave? The government commands the demolition. How dare you confront the government?" 
The citizens' definition of "demolition": the adjustment of property relations between independent subjects To change the above situation, Mr. Luo, the representative of the Grand Litigation, began to research relevant laws since 1995 when his house was demolished. Based on the laws legislated by the central government-"land-use rights can be transferred according to regulations in laws" in the amendment of the Constitution as well as "land-use rights should be legally obtained " in the eighth item of the "Regulations of Urban House Demolition Management" by the State Council, Mr. Luo redefined demolition as an adjustment of property relations between equal subjects, which should be legally carried out.

Mr. Luo: Why is City B in such a situation? They believe that urban land belongs to the state according to The Constitution enacted in 1982. So the original owners no longer had the land-use rights. They were confiscated. Secondly, they take a step back, since the Constitution stipulates that urban land belongs to the state, the land-use rights of these homeowners were either acquired through transactions from the state or allocated by the state, so they can take them back without compensation whenever they need. .... City B was very concerned with this problem and consulted with the Ministry of Construction. The latter was not able to reply and submitted this problem to the Legislative Affairs Bureau of the State Council. They asked whether the land-use rights of homeowners should be compensated during demolition. They converted the adjustment of property relations to issues of compensation. These are two different things. The Legislative Affairs Bureau replied, saying that when demolishing private houses, they should strictly abide by the laws and the "Regulations of Urban House Demolition Management," implying that the bureau did not agree with their points. (Record of public forum on Sep. 4, 2006)

Through the practice of rights defending, the property rights of homeowners specifically embodied in land-use rights became more clear. For example, the "citizens' submission"submitted to the central government in recent years mentioned ${ }^{8}$ :

After the implementation of nationalization of land ownership-which separated the ownership and use rights of land-citizens obtained independent land-use rights with an indefinite period of time. The property rights over the land (enjoyed by the citizens) were transferred from land ownership to land-use rights. ("Opinions on 'the Draft Ordinance of Levy of and Compensation for the Houses on State-owned Land"” February, 2010)

Based on the legal philosophy of property rights, actors repeatedly stressed that "compensation for resettlement" and "the adjustment of property relations" were two entirely different issues. In the statement by Mr. Bei, another representative of the Grand Litigation, an independent self with a firm boundary has already appeared.

Mr. Bei: Compensation is determined by policies. There is no legal basis for it. He can propose five thousand and you can raise it to six thousand for your losses. The adjustment of property relations is another subject. It has a legal basis. The second item of "The Civil Law" says that it applies to the adjustment of personal and property relations among legal persons and citizens. It is effective among civil 
subjects, and the state is also a civil subject, and we are both civil subjects.

Government exercises authority on behalf of the state. It can only dispose of its own properties. It cannot dispose of and allocate civilians' properties.

(Field interview on Dec. 14, 2005)

The state-individual relationship in practice is clearly very complex: as the incarnation of the state in an abstract sense, the central government plays the role of an ideological repository, whereas the local governments and actors each take what they need. The actors selectively construct different state-individual relationships with the central and local governments, showing a selective firming mechanism of their self-boundary. This reflects the paradoxical process of rights defending in contemporary China-fighting against local administrative departments is premised on one's internalization of the legitimacy of the central government. This is caused by the transitional strategy of liberalizing the economic sector but controlling the political sector. Also, it reflects the transitional state of Chinese society-moving forward from a traditional state to a modern state-and demonstrates the uniqueness of China's transformation.

\section{Selective firming of the self-boundary}

With the selective firming mechanism, actors make specific judgments in different situations-whether they should construct permeated boundaries or closed boundaries, in accordance with the subordinate or equal state-individual relationships. The mechanism unfolds according to three specific factors related to urbanization-laws, land, and developers. Through splitting the levels of governance, analyzing the dual identity of the state in the land-tenure system, and separating the political and economic functions of the totalitarian state, actors struggle to narrow the scope to which traditional subordinate state-individual relationships can be applied, while expanding the scope to which modern independent state-individual relationships can be applied. These changes show the reshaping of the state-individual relationships through the transformation of the self-boundary from permeated to firm and the self-concept from inclusive to exclusive.

\section{Focusing on laws: Splitting governmental levels of the state}

(1) Laws as weapons-associating levels of law with levels of government

"Defending their rights in terms of laws" is the most important feature and strategy of this collective litigation'. Different from other urban social movements in the same period, which treated different laws, regulations, and policy documents all as laws, the actors in this case distinguished laws based on the levels of the law-making departments. According to the ordinal sequence of Constitution-level laws (such as the Land Management Law), the State Council-level ordinances (such as the Regulations of Urban House Demolition Management), and local-level regulations (such as the Implementation Rules of the State Regulations of House Demolition Management), actors strictly sorted relevant laws and regulations when applying them to the process of land exploitation. Only the central government-level laws and regulations (the Constitution, some basic laws, and the regulations enacted by the State Council) were treated as laws in the framing of their rights defending. Laws thus reflect an apparent ideological implication-they are the embodiment of the guidance from the central 
government. By comparing the regulations and laws at the local level with those at the central level, the actors determined that local governments, as executive agencies, violated the policies of the central government. Consequently, they ideologically excluded local governments from the original framework of the state, which previously was capable of requiring the individuals' obedience by law.

Mr. Bei: I can tell you that this method is pretty simple. Look at the state's laws, and then compare them with the administrative rules of City B. Another hint: the administrative agencies are executors. They should execute "laws." ... In other words, local authorities should enforce laws without adding their own stuff. The stuff they added, like administrative rules and regulations, must conform to laws, otherwise they are invalid. Local governments cannot invent something by themselves and set them as laws, saying you should have everything done accordingly. That's not how it works. The local rules contradict the laws, so they are invalid. (Field interview Nov. 23, 2005)

"The Grand Revelation Letter" provides ample facts, fully exposing the fact that previous administrations of governmental officials who were in charge of land leasing of City B, the Municipal Housing and Land Administration Bureau, the district-level governments, housing and land bureaus, and public security departments, and people's courts at different levels participated in the real estate development. They deceived superiors and duped subordinates, ignored laws, illegally administrated the city, and violated laws during their enforcement of laws. (Introduction to the Grand Revelation Letter, 1999)

Specifically, the difference between the laws of the central state and the rules of local state mainly occurs in the land acquisition stage during demolition. Local governments realized their goals through changing the text of central-level laws, finding loopholes, substituting procedures, and reversing the order of procedures. In addition, they took advantage of the gaps between real practices and rules in texts during their execution (for details see Shi 2012). From the actors' view, these were the bottlenecks where "local governments did not comply with the central government-they agreed overtly but opposed in secret" (field interview, Sep. 25, 2005).

\section{(2) Administrative proceeding: the production of egalitarian (local) state-individual}

\section{relationship}

Compared to other actions of rights defending in the same period, the Grand Litigation was distinguished by its insistence on administrative proceedings. According to the statistics of the respondents, in 1995-2000 a total of thirty-three groups submitted their administrative proceedings, involving 20,758 plaintiffs whose houses had been demolished. Defendants involved the Land and Housing Bureaus at the municipal and district levels as well as the Municipal Government; in the subsequent appeal process defendants also involved courts of preliminary trials and secondary trials (based on field interviews on Nov. 11, 2005 and Nov. 24, 2005). The differences ${ }^{10}$ between lawsuits and petitions to upper-level governments are summarized in Table 2.

Objectively speaking, compared to other strenuous methods of rights defending, firmly upholding litigation over a relatively long course is rarely seen. Existing literature 
Table 2 Comparison of litigation and petitions

\begin{tabular}{|c|c|c|}
\hline & Litigation & $\begin{array}{l}\text { Petitions to upper-level } \\
\text { governments }\end{array}$ \\
\hline Framing logic & Rights based on laws & $\begin{array}{l}\text { Grievance attributed to administrative } \\
\text { problems }\end{array}$ \\
\hline Forms of appeal & United appeal & Fragmental appeals \\
\hline Procedures to appeal & $\begin{array}{l}\text { Clear since it is stated } \\
\text { in procedural laws }\end{array}$ & No clear procedure in text \\
\hline $\begin{array}{l}\text { Controllability and predictability } \\
\text { of outcome }\end{array}$ & $\begin{array}{l}\text { Controllable procedure; } \\
\text { unpredictable outcome }\end{array}$ & Totally out of control and unpredictable \\
\hline Impact on social stability & Beneficial to social stability & Jeopardizes social stability \\
\hline $\begin{array}{l}\text { Relationships between the two } \\
\text { parties of the protest }\end{array}$ & Equal and independent & Subordinate and affiliated \\
\hline Self-concept & Boundary-firm self & Boundary-permeated self \\
\hline State-individual relationship & Egalitarian & Subordinate \\
\hline
\end{tabular}

on litigation and petitions share a common view-Chinese people prefer to use petitions in resolving their disputes. Both the numbers of petitions and administrative proceedings in national surveys or small-scale surveys support this conclusion (see Zhang 2009). After nullifying the theories of ineffective lawsuits and growing weary of lawsuits, as they do not agree with historical facts, some scholars have proposed that the Chinese people prefer petitions due to the lack of mediation sessions and the overabundance of confrontation in the courts. In comparison, though less efficient, petitions are more moderate and have less possibility of "breaking up with each other." Through petitions people tend to gain a "culturally comfortable feeling"11 (Zhang 2009). From the perspective of this paper, as a type of lawsuit in which people sue the government, administrative proceedings are the choice of the weakly positioned actors to adjust the state-individual relationships. They exhibit an independent self with a firm boundary against the local state in a concrete sense, which is essentially the reconstruction of the relation between the local state and the individual by defining them as two equal subjects. It is this search for equality with authority, encouraged by faith in the law, that guides the actors to detach themselves from the "cultural fitness", and to firm their permeated self-boundary, which generates citizenship.

\section{(3) Letters of revelation: the maintenance of subordinate (central) state-individual relationship}

After pulling the local governments out of the state in traditional unification, actors form a psycho-alliance with the central government through constructing a consistency between their rights defending and the national interests of the economy and politics. Actors believe that the local government illegally allocated their land and violated their private property rights regardless of the state's and individuals' land-use rights; the local government's action also caused losses to the state. According to the statistics presented by this litigation group, changing the purpose of the administrative allocated land from reconstruction of old and dilapidated houses to build high-grade houses, apartments, and office buildings led to a loss of 43.45 billion RMB (about 7.1 billion USD) in the price 
spread in the transfer fee of state-owned land. The actions of rights defending were thus not only to protect private property rights, but also to recover the property losses of the state. Meanwhile, the actors also politically defined the corruption of the local government as deeds that undermined the legitimacy of governance and the dignity of laws, and damaged the image of the state. As reiterated by the litigation group in their "revelation letters"12 submitted to the Central Commission for Discipline Inspection (CCDI):

Since the government decrees on anticorruption by CPC Central Committee (CPPCC) have not been implemented well, four major corruption cases could not be investigated and handled; two serious unconstitutional and "illegal events"- the massive deprivation of property rights and litigation rights in order to illegally possess citizens' properties-cannot be legally corrected. This seriously undermined the unity of the state and the dignity of socialist rules. Moreover, they not only sabotaged the foundation of "ruling the country according to the law" and severely impaired the social and economic order, but also seriously damaged the image of the Party and the people's government. Furthermore, these unconstitutional events also threatened the credibility of the Party and the government, damaged social stability, and jeopardized national security, resulting in heinous political influences and the vehement dissatisfaction of the people of City B.

In addition, through references to a variety of ideological discourses since the early days of PRC, the actors not only enhanced the legitimacy of their rights defending but also highlighted the local governments' violation of citizens' rights. What's more, the quality of citizens who were aware of the national situation and guarding the interests of the state is also emphasized, which is achieved by containing the state within the self through the expansion of individuals' permeated self-boundary. Thus psychoconnections between individuals and the abstract-sense of state occur with moral implications producing legitimacy for the action.

Despite the many grievances (physical and mental) us relocatees have suffered, we keep studying the laws, being aware of laws, using laws, and abiding by laws. We believe in the CPCCC's commitment to anticorruption, and are always consistent with the pace of the CPCCC; all our deeds have been in accordance with laws and legal procedures. Had we demonstrated in the streets or acted like corrupt officials in the government and courts who disregard laws, City B could not have achieved such good social stability. If corrupted officials in the government and courts regard citizens who know, study and abide by laws as a sign of weakness, it would be absolutely wrong, and there will be very serious consequences. ("An open letter to the Municipal People's Congress of City B," 2000)

By actively constructing their direct association with the central government, the actors weakened the legitimacy of the local government. "The Grand Revelation Letter" repeated the expression "[their deeds] could not be tolerated by the state's laws" to distinguish the boundaries between the central government and the local government, and between the state and individuals. 
The loss of more than one hundred and thirty billion RMB [about 21 billion USD] in City B disrupted the macroeconomic control and the social economic order of the state. The state's laws should not tolerate it. ... Complaints arose all around; some people's anger has contributed to their illness; some have died feeling a deep sense of unfairness; some were beaten by policemen; some were detained for no reason; and how many have suffered from decreased living standards because of this? Every cent of it - more than one hundred and thirty billion RMB - is the result of people's blood and sweat; corrupting even one cent of it is evil and should not be tolerated by the state's laws. ... They defied the state's laws, violated citizen rights, and deprived the citizens' of their property rights; it is infuriating. ("The introduction to 'the Grand Revelation Letter," 1999).

\section{Focusing on land-differentiating the dual identity of the abstract state}

Regarding urbanization, the greatest confusion caused by the state was an ideology-laden concept of land, which provides local governments with the state's endorsements of their legitimacy through land acquisition. In this case, the actors' selective firming of their self-boundary was reflected in the further splitting of the abstract state into the subject enjoying ownership or use-rights of the land. When the state is regarded as the ideological owner of all national urban land, subordinate state-individual relationship is applied between the state and the actors. However, when the state is regarded as the practical owner of the land-use rights, independent state-individual relationship is applied between the state and the actors. By this strategy, the scope for the subordinate state-individual relationship based on a permeated boundary is again narrowed, indicating the selective firming process.

The nationalization of private land guided by the socialist ideology was the starting point of the discrepancy between the legal interpretations of the land-use rights by local governments and citizens. Actors believed that the nationalization process was needed during the ideological construction of socialism. Thus the state nationalized the ownership rather than the whole property rights of land. The essence of this process was the detachment of the land ownership and the land-use rights. The ownership of land went to the state, while the citizens continued to possess the land-use rights, which becomes part of the property owned by citizens. However, the local governments regarded nationalization as including the confiscation of the property rights to land. The split of the land ownership and the land-use rights contributed to the split of the dual identity of the abstract state. Actors thus further refuted the logical basis of the local governments' arguments, such as the idea that the land-use rights of private housing are allocated by governments, and could be recovered for free due to urban development needs. Ownership changes brought by the nationalization of land, summarized from the actors' view ${ }^{13}$, are shown in Fig. 2.

\section{(1) The state as the subject entitled to land-use rights}

Faced with indiscriminate allocation by the arbitrary state power during demolition, the actors questioned two points. Firstly, the state could not allocate privately owned property (land whose land-use rights were owned by citizens). Secondly, even when allocating its own property (land whose land-use rights were owned by the state), the state needed to distinguish between paid allocations and unpaid allocations 


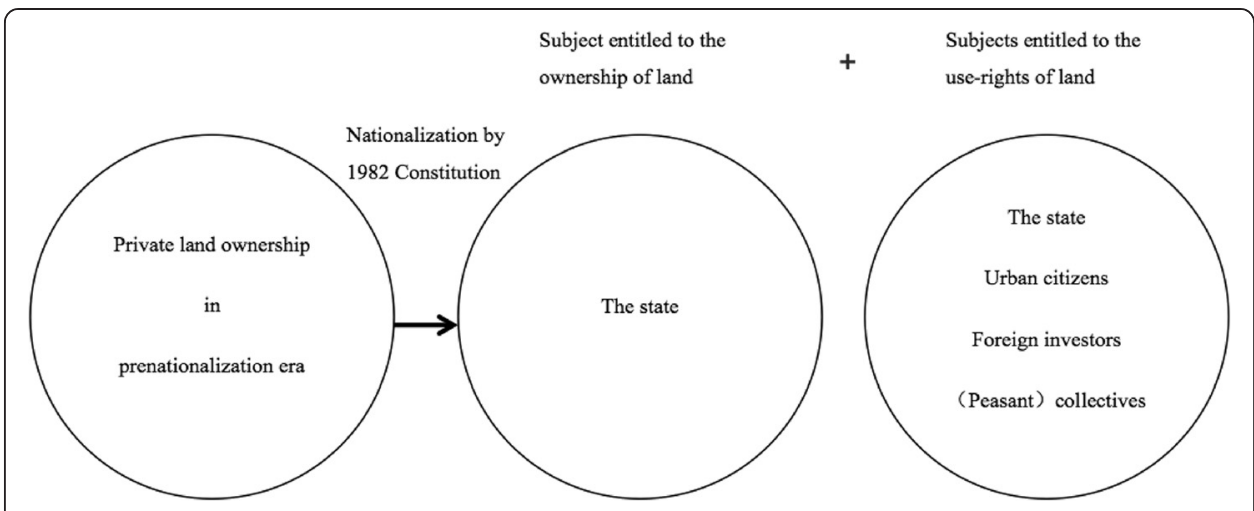

Fig. 2 The deriving of land-use rights from land-ownership: an interpretation of the Chinese land nationalization from the actors' view

based on whether there were people living on the land. Thus the state developed different property relationships with individuals as owners of private housing and tenants of public housing, concerning specific property rights such as the land-use rights and the relocation fees for citizens.

A. Between the state and owners of private housing In this framework of rights defending, it is the land-use rights derived from pre-revolutionary private housing during nationalization of land ownership that has become an exchangeable good with great value in the real estate market. As the owners of land-use rights, the state and the private homeowners are subjects that share equal rights and legal status, meaning that they could separately develop civil relations with the third parties (i.e. investors) during the process of urban renewal to transfer land-use rights in accordance with the relevant laws. Therefore allocation as an action with administrative enforcement could not be used to change the property relations between equal entities; it was applicable only when the land-use rights were owned by the state itself.

The people's government has the right to dispose of state-owned property according to laws, but does not have the right to dispose of properties of citizens. ("The administrative proceeding" by Mr. Bei's family, July 1999) In accordance with the principle of uniting houses and land, the Regulations of Urban House Demolition Management states: "land-use rights must be legally obtained by whoever needs them during demolition." Namely, when the owner of houses is the state, investors should obtain the land by transfer or paying lease to the state; when the owners are citizens, they should obtain the land-use rights from citizens by conveyance or transfer ("The background material of Grand Litigation of Ten Thousand Plaintiffs," Feb. 2000)

B. Between the state and the tenants of public housing For the tenants of public housing who accounted for a larger part of the population in the demolition of the inner city, the state had corresponding land-use rights and could allocate or transfer this land. However, the actors suggested that even in this case there should be two different kinds of settlement-allocation with payment and allocation without payment. The former 
meant that the government should pay relocation fees to those who lived on reclaimed state-owned lands.

According to the laws, during the development of urban real estate (construction of municipal infrastructure and houses), new land users must acquire the land-use rights of the state-owned land (the land-use rights derived from the state ownership of land) through transfers. New land users must pay relocation fees for residents within the scope of allocation. The standard for urban relocation fees is based on the benchmark price of the land and the number of relocated households in a specific case. The local government should not charge relocation fees (laws related to allocating land-use rights and benchmark price of lands clearly stipulate it).... [For land of public interest,] new users (such as the municipal authorities or state organs, and the construction unit of affordable housing, etc.) should pay relocation fees to the residents. The fee should be included in the budget plan of national basic construction and paid by the state's treasury. [For land for commercial use] new users (real estate investors) should pay residents their relocation fees. These payments should be included in the cost of real estate development and paid by developers. ("The background material of Grand Litigation of Ten Thousand Plaintiffs," Feb. 2000)

These two aspects were subsequently unified under the framework of property rights.

Mr. Luo: The reason why we can form an alliance for a lawsuit is because our property rights have been violated. What are property rights? For citizens, the violated properties are the Chinese yuan that the government should have paid. For private homeowners, they are land-use rights. For tenants of public housing, the violated rights are the rights to use their houses indicated in relocation fees. ... the Grand Litigation is composed of all rights holders on urban state-owned lands. (Interview on semi-open public forum on Dec. 12, 2004)

By adopting rights discourses with specific content of property rights, the actors strove to distinguish the adjustment of property relations based on laws and the compensation of allocation and resettlement based on administrative directives. The former was the goal for which the actors struggled; they defined themselves as private property owners, subjects who had equal land-use rights as the state. Their call for an independent self with a firm boundary was apparent. The latter shows the reality of the history and the current situation of urban demolition; the state emphasized its single identity as the preeminent landowner and continuously required individuals' submission through a boundary-permeated self.

\section{(2) The state as the subject entitled to land ownership}

The state has another role in the ideological level of land-the owner of the land. When the state held this identity, the traditional subordinate state-individual relationship came onto the stage. In the name of public interest, the state positioned itself at the highest point of morality, demanding that individuals be subject to its rules and extending the traditional permeated self-boundary. However, in order to avoid the state's insatiable invasion, individuals used every possible method to limit the scope of invasion carried out in the name of "public interests". In early administrative proceedings, an initial boundary between public interest and personal property already existed: 
For the need of public interest, the state can readjust the usage of land. Plaintiffs can comply with "The Law of City Planning" and support urban planning, but cannot lose their properties in demolition. The state protects citizens' properties; the Constitution protects citizens' properties. ("The administrative litigation" by Mr. Bei's family, July 1999)

In recent years, public interest has been further defined and distinguished from citizens' submissions to the central government; the development of real estate was explicitly excluded.

In legal provisions the construction of "the needs of the state's public interest" should be characterized as a project approved by the state, the land used by the state, and the construction invested by the state. All business activities of real estate development are not included ("The secondary opinions for 'the draft ordinance of levy and compensation for houses on state-owned lands," Dec. 2010)

After defining public interest, the citizens' submissions also addressed the question of how to define these needs and further elaborated the question of how to examine the necessity of needs:

In the Constitution, the state's needs of public interest stipulate that the construction projects must comply with both public interest and needs. Only by meeting both of the conditions can governments levy immovable properties from the citizens. The keyword here is "both." A large number of projects in practice reflected the state's public interests, but were not necessary. ... These projects were all established and approved by governments. Whether they were necessary was not checked. The original "state's need of public interest" stipulated in the Constitution was replaced with "the public interest". As long as they were of public interest, governments could levy lands for them and consequently expanded their scope of imposition. It violated the property rights of citizens and wasted the money of taxpayers. So for these two prerequisites, the government should develop a strict approval process for construction projects. Particularly, the government should publicize the reasons of the needs to the public, and accept supervision from all taxpayers and relocatees. Additionally, projects should also be approved by the People's Congress at various levels of government. ("Opinions for 'the draft ordinance of levy and compensation for the houses on the state-owned lands," Feb. 2010)

Thus, after splitting the state into the central level and the local level according to its governance function, the actors further made a split of the central state in the abstract sense, which nominally owned all land. By regarding the state as the owner of the land-use rights, actors attempted to construct an equal and independent state-individual relationship based on the spirit of the contract supported by the market, indicating the appearance of a firm self-boundary during the transformation. Meanwhile, by treating the state as a landowner, actors on the one hand acknowledged the moral obligations demanded by the national self under the banner of "public interest," activating the traditional subordinate state-individual relationship. On the other hand, through explicitly defining "public interest" and "needs," the actors clearly distinguished the 
demolition situation from the unconditional obligations in traditional culture. This also implied the effects of the independent self-boundary.

\section{Focusing on developers: Splitting the dual functions of the concrete state}

One of the important factors in China's reform was that the market was introduced under the guidance of the state. The real estate market in the early 1990s is an important example. It was a market with a strong political and policy nature (Xiao 2009). Both the pattern of " combining dilapidated house renewal with real estate development" and the high degree of overlap in the personnel of development companies, demolition companies, governments, and courts show the high degree of entanglement between the totalitarian state and this new market, which empowered the developers with immense administrative force. Thus, besides the direct state-individual relationships via governmental agencies discussed above, another path associating the state with individuals should also be elaborated, which is via the market. In this case, in addition to gradually locating the state through a firming self-boundary, actors also attempted to extract the state's administrative functions from the market functions in real estate development. By restoring developers to the status of businessmen, and having administrative relations revert to trading relations under the concept of the market, the actors constructed their independent self and firm boundary against the market and, subsequently, against the state during demolition practices.

An early text, called "Principles of this Litigation Case," that disseminated the philosophy of the actors focused on the nature of the developer and elaborated the relationship between the relocatees and the developer as well as the rights and obligations of both parties. It claimed an equal rather than an affiliated relationship between the developer and the relocatees.

What is the relationship between WFJ Developmental Company and relocatees?

The relationship is equal. WFJ is a developer, a businessman. We are not in an affiliated relationship. It is between a relocator and the relocatees. We are the two parties in this specific case. The third item of "the Civil Law" clearly stipulates that parties shall have equal status in a civil activity. The sixth item in it also mentions that civil activities must comply with relevant laws, regulations, and national policies. Rights and Obligations of WFJ Developmental Company:

Before enjoying their rights--acquiring the land-use rights of state-owned land--WFJ must first fulfill their obligations according to laws.

Obligations: based on benchmark land price (note: see the No. 34 file of 1993 by the government of B City), developers should pay: 1. Land transfer payment; 2.

Infrastructure construction fee; 3 . Urban relocation fee. Among these payment and fees, the first and the third should be given to recolatees; the second should be given to the state.

Rights: After fulfilling the obligations above, WFJ could then acquire the use right of state-owned land, enjoying the right of gaining financial benefits from their real estate development.

What are the obligations and rights of relocatees? 
Rights: Relocatees have the right to freely choose places of residence (should not be placed unilaterally). The No. 37 item of the Constitution stipulates that citizens' liberty is inviolable. According to the No. 34 file of 1993 by the government of B City, relocatees have the right to receive relocation fees.

Obligations: Relocatees must move away and vacate their houses for WFJ while enjoying their rights.

The intervention of administrative power into the supposedly equal and civil relationships between the developer and relocatees became the main reason why plaintiffs (the rights holders of private housing) sued the governmental department (the Land and Housing Bureau) in court:

The Civil Law states: parties have equal status in civil activities. ... The third party (WFJ) is a real estate development company for the purpose of profit. WFJ and the plaintiffs are two equal civil subjects; there is no affiliation. Since obtaining its permission for planning, WFJ has established an equally civil and legal relationship with the plaintiffs. The Principles of the Civil Law are applicable to the adjustment of the property relationships between the plaintiffs and WFJ.

Both parties have their rights and obligations. The plaintiffs enjoy the right to compensation, resettlement, and free choice of their new residence places through equal consultation. Meanwhile, the plaintiffs should fulfill the obligations of relocation in accordance with the agreement. The third party must bear the obligations mentioned in "the region's benchmark price of land of the year 1998" before getting the right of applying for land-use rights.

However, the defendant violated the stipulations in the Civil Law by approving a third party to unilaterally make the compensation and resettlement plans. The defendant turned the equal relationship between the plaintiffs and the third party into an affiliated relationship in which the plaintiffs had to be obedient to the third party. ("The administrative litigation of C District," June 1999)

Different from some cases of rights defending in which relocatees strategically chose developers as defendants, the actors in this case always pointed to state-individual relationships. By detaching the inextricable connections between the state and the market, they aimed to clarify the independent boundaries between them and the concrete-sense state that was represented by the Land and Housing Bureau of B City.

In the court and on other public occasions, the responsible person of the Land Policy Branch of the Land and Housing Bureau and the arbitrator of the court publicly said: "After obtaining the permission for demolition, the real estate developer is working on behalf of the government. You [referring to citizens] must accept their resettlement plan." ... Because of the illegal behavior of the above administrative department and the People's Court of X District, commercial behavior by the real estate developer has turned into governmental behavior. ... As long as citizens resist illegal infringement by the real estate developer and protect their property and residence rights [the freedom of settlement and residence] according to laws, they would receive illegal adjudications, illegal approval of the deprivation of their land-use rights, and illegally forced eviction. ("The Complaint Letter to the NPC Standing Committee," July 1997) 
It is worth noting that such expressions usually very specifically address the Land and Housing Bureau of a certain district so as to be distinguished from the state in the abstract sense discussed above, to which citizens should be subordinate. Here the actors split the administrative and economic functions of the state. Specifically, they defined the concrete administrative departments as "the regulators and supervisors of urban demolitions." They reduced the state-controlled market to a free market in order to achieve free and equal transactions between independent subjects as individuals, developers, and government agencies, reflecting the third dimension of the firming mechanism of the self-boundary.

\section{Discussion and Conclusion}

China has been undergoing a great transformation, changing from a totalitarian system to the host for market and a relaxed society. This process is entirely different from the process in Western history, during which the emergence of civil societies proceed the generation of markets and the construction of the states. The Chinese transformation can be regarded as a process during which a new equilibrium is being achieved; at this moment what we are experiencing is an imbalanced stage in the middle of two equilibrium phases. The equilibrium also has a twofold meaning. The first is the balance among various elements of social structures, as elaborated under the framework of state, market, and society in the existing literature. From the perspective of social psychology, the balance also includes the correspondence between social members' cultural-psycho structures and social structures. Yet this perspective has been rarely touched upon in previous studies. Therefore, the significance of introducing this perspective lies in the idea that the individual, as a microanalytical dimension, is introduced to the tripartite framework of state, market, and society. This allows the study of the specific bearers during the transformation-to see how individuals directly or indirectly (via market and society as mediums) reconstruct their state-individual relationships through the transformation of self-construal. Through this reconstruction, cultural-psycho structures once again correspond with social structures.

The traditional boundary-permeated self, featuring an elastic self-boundary and the corresponding subordinate state-individual relationships, fit well with the totalitarian society of the pre-reform era. The problem of the absence of society was concealed because of the social rights provided by the danwei system, but later triggered the overwhelming imbalance at the birth of the market during the transformation. The alliance of the state and the market contributes to the imbalance. Meanwhile, it was the flexibility and permeability of the self-boundary that further allowed the arbitrariness of state power and enlarged the scope of its coercive force. Through a series of social conflicts since the mid-1990s, we can decipher the following characteristics of individuals and the state. The individuals inherited a boundary-permeated self; they were individuals who were mobilized by the socialist ideology in the period of planned economy and required to unconditionally obey the will of the state. What's more, after the dissolution of the danwei system, individuals were atomized without self-organized associations. On the other side, the state is the one who possesses political and economic resources, as well as the high point of morality claiming urbanization and modernization as common interests. A startling disparity existed between these two forces. Imbalances 
among the various elements of the social structures and between social structures and cultural-psycho structures formed a manifested dual imbalance that could serve as the explanation for frequent social conflicts in that period. From a positive view, this process in the form of social conflicts was a signal from the state to further relax the society after introducing the market. It was also a process in which individuals autonomously updated their traditionally flexible and permeated self-boundary under the framework of the differential mode of associations to the firm one generated during the market economy and modernization. Ultimately, after the reconstruction of state-individual relationships, social elements in both structural and psychological levels will return to equilibrium again.

However, this firming process of the self-boundary is full of hardships, not only because of the very limited institutional space in the current system but also because of the continuously strengthened ideology of a supreme state and the long-suppressed awareness of individual rights and a self-organized society over the past five thousand years. This situation is further highlighted by the reform's strategy of containing simultaneously an open economy and a closed regime. Consequently, faced with infiltration into their private areas, actors have to create both the legitimacy of their rights defending and their opportunities for protest. From the perspective of state-individual relationships, China's paradox lies in that individuals' detachment from the concrete state (by constructing modern and egalitarian state-individual relationships) is actually premised on their internalization of the abstract state (by acknowledging the traditional subordinate state-individual relationship). Selective firming of the self-boundary is an adaptive mechanism for coping with that paradox under such historical and current situations.

In this research, the selective firming is illustrated along three dimensions: firstly, actors view laws as the embodiment of central government guidance and the texts that stipulate rules. They further split this dual role into the abstract and concrete aspects of the state, at the ideological and administrative levels respectively. Moreover, through distinguishing the land-use rights and the land ownership, actors differentiate the dual identity of the state. While narrowing the scope in which subordinate state-individual relationships are applicable, individuals also expand the scope to which egalitarian state-individual relationships can apply. Furthermore, by renewing the definition of developers, actors simplified the state to the most specific administrative and executive departments. They reiterated the state-individual relationships by redefining the market-state relationships and finally achieved the firming of their self-boundary. This triple mechanism is shown in Fig. 3 below:

The logic of this mechanism is as follows: although inheriting the subordinate state-individual relationships (marked by the dashed circles in Fig. 3), actors can narrow their applicable scope through the triple split above. They can gradually contrain the currently dominant political power by expanding the applicable scope of equal state-individual relationships, based on contractual ideas and individual rights (marked by the solid circles in Fig. 3). At the individual level, this process features the firming of the self-boundary and the generation of independent individuals; in a macro-perspective, the process is characterized by the state's transformation from an overall unification to a modern country with separate parts of state, market, society, and individuals. In the end, this process will reach equilibrium again. 


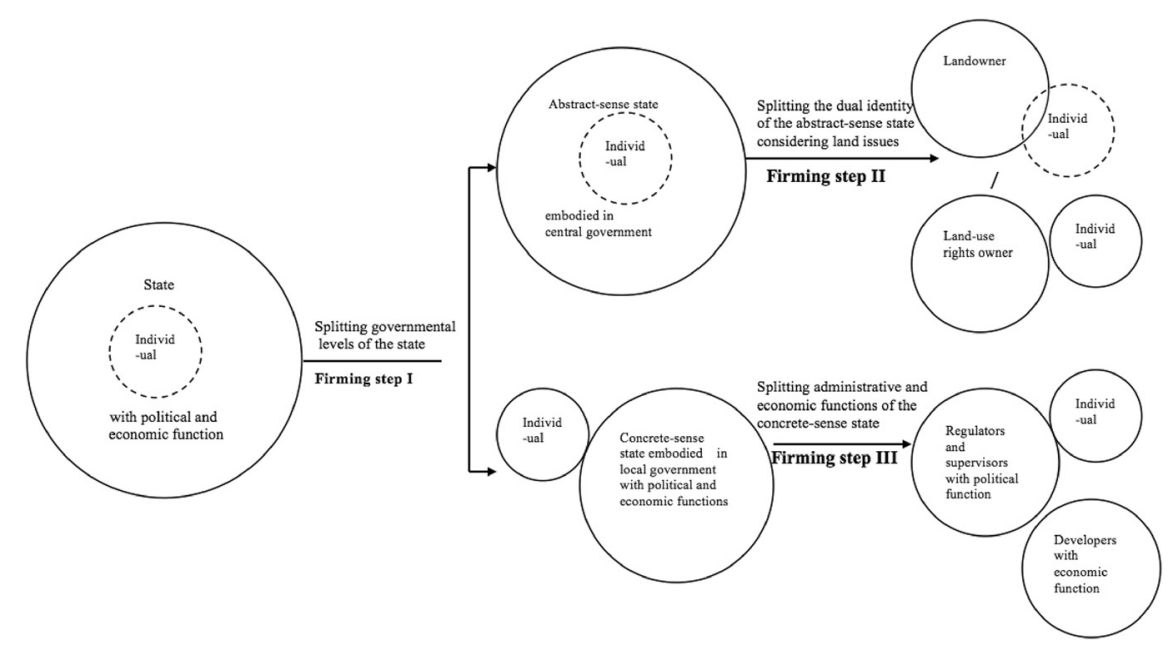

Fig. 3 "The selective firming" mechanisms of the self-boundary and the differentiation of social structures. Note: Following the direction of the arrows, state-individual relationships evolve from inclusive and subordinate to independent and equal, whereas the self-boundary transitions from permeated to firm.

\section{Endnotes}

${ }^{1}$ To emphasize the "rights" which have already been infringed, here chose "rights defending" instead of "rights protection" for the Chinese words "Weiquan". Actually, the rights defending movement related to land issues in contemporary China is rather a reactive than a proactive movement in Tilly's framework (Tilly et al., 2003)."

${ }^{2}$ "Self-boundary," "self-construal," and "self-schema" constitute the main content of the concept of self from the perspective of social psychology. "Self boundary/self-nonself boundary" is related to how exactly one includes or excludes others from the self in different cultures. "Include" means containing others within one's self, while "exclude" means integrating oneself into a group composed of others. Due to the basic characteristics of the differential mode of associations in Chinese culture, the self-boundary is especially important for the understanding of Chinese people's self. Yi-yin Yang found that when given different scenarios, Chinese people used different self-boundaries (permeated boundary to include others or firm boundary to exclude others) in regard to environmental requirements. In more traditional cultural contexts, people are more likely to use permeated boundaries. The main features are as follows: autonomy (self-centered control of including or excluding others); permeability (including significant others); scalability (the number of included people varies by the significance of others); switchability (in certain situations, people firm and close their boundaries of self, which yields intended meaning of this word unclear-"leads to"? "constrains"? membership); morality (the direction of morality evaluation embedded in the Chinese self-concept; by containing the nation within the self and becoming part of the "me" appraisal though a permeated boundary, one achieves an advancement in one's morality (Yang \& Zhang 2008, 36-37).

3 "Totalitarian" refers to the state in the previous planned economy era that the state controlled and dictated the rest of these four parts, carrying on traditional unification mode. No market, society, or individuality was allowed (Yang 2008) compared to expecting future after transformation in which the state, market, society, and the individual were separate from each other. For the state-individual relationship discussed 
here, the totalitarian regime also implies an integrated relationship between the central state and the local state.

${ }^{4}$ This concept was first proposed by Sampson (1988) when he discussed "individualism." He pointed out that for people with self-contained individualism the boundary is firm and the self-concept is excluding; for people with ensembled individualism the boundary is fluid and the self-concept is including. However, Sampson did not link the characteristic of self-boundary with the structure and culture of different societies. Indigenous psychology further emphasizes "autonomy" (self-centeredness), selectivity (different principles are applied in different situations to interactions with different individuals who one includes or excludes), and "dynamics" (control of the changes in boundaries) embodied in the sense of differential mode of associations with respect to Chinese people's concept of self (Yang 2008, 35). This study integrates the progress of indigenous psychology into analyses of permeated and firm self-boundaries and further extends the discussion to the different forms of state-individual relationships.

${ }^{5}$ After the founding of the People's Republic of China land reform was contentious in rural areas but gradual in cities. Compared to rural areas, evolution of the property rights of urban land was more complicated and equivocal-most private real estate had been "socialist reconstruction" and became resources for the first public housing after several social movements, such as the Public-Private Partnership and the Cultural Revolution. Land reform has become a concrete part of the construction of the planned economy. As a consequence, a large number of actual users and house owners were separated from each other; this led to misinterpretation of ownership and user rights when the state initiated the real estate market. In the survey respondents always stressed that although the deeds for houses and land that could prove their ownership had been taken away in political movements, the legal change of their ownership had never been completed. Those deeds were still archived in the local bureau of Housing and Land. In other words, citizens still hold legal property rights over those houses and land.

${ }^{6}$ Actors vividly called it compensation for bricks and tiles after the depreciation of "substance on the ground.

${ }^{7} \mathrm{Lv}$ Xiaojing, 1998, "The land-use rights of demolished historical legacy of individual private houses shouldn't be financially compensated according to the law," B City Daily, November 4, 1998.

${ }^{8}$ On Jan. 29 and Dec. 15, 2010, the Legislative Affairs Bureau of the State Council published the full text of "The Ordinance of Levy and Compensation for Houses on State-owned Land (public draft)" and "About the Levy and Compensation for Houses on State-owned Land (second public draft of ordinance)" on its Web site to seek the views of society. Accordingly, the actors submitted two files signed by 5,479 citizens in B City. They are "The Opinions on 'the Ordinance of Levy and Compensation for the Houses on the State-owned Land (public draft)" and "The Suggestions on Immediate Abolition of 'Regulations of Urban Housing Demolition Management' and Legislation of Expropriation" on Feb. 10, 2010, and Dec. 29, 2010.

${ }^{9}$ The strategy in this case is illustrated by two dimensions-"defending rights according to laws" and "setting laws as the principles of actions." The former refers to the demands of strict jurisprudence of the ways for expression, content of lawsuits, and methods of mobilization. The latter refers to the fact that actors also act in strict accordance with laws in their rights defending. Actors' dual understanding of the term 
"according to laws" also shows the simultaneous construction of both the legitimacy and the opportunities of their rights defending.

${ }^{10}$ From the point of view of this work, litigation is the philosophical unions of individuals with firm self-boundaries. Based on the violations of universal rights, litigators framed their grievances with rights discourse with concise and unified appeals, and aimed at promoting social legal systems. Petitions to upper-level governments, then, are the geographic unions of individuals with permeated boundaries. Based on individually unfair treatments, petitioners framed their grievances with fragmented and uncompromising appeals as "redressing injustices" and that aimed at solving personal problems. Therefore, although they are the only two channels of appeal in the current system, they are entirely different in generating modern and independent citizens with firm boundaries.

${ }^{11}$ In Zhang's study the term "comfortable feeling" refers to the idea that, faced with problems, people tend to adopt solutions that are subconsciously easy to accept or in line with their cultural habits.

${ }^{12}$ Since 2001 this litigation group has entered the stage of impeachment and continuation. They annually submit one or two revelation letters to the leaders of the central government and its relevant departments. Thus far they have reported the injustice they experienced sixteen times. The revelation letters were signed in the names of "the relocatees in City B" or "B City citizens"; the number of signatures varied from ten thousand to over twenty thousand.

${ }^{13}$ Given the background of investment promotion by governments in real estate in the 1990s, actors distinguished the state, citizens, foreign investors, and (peasant) collectives as four independent and equal subjects when defining land-use rights. For instance, "the administrative proceeding" by Mr. Bei's family in July 1999 mentioned: "private land-use rights are neither gained through transfers nor allocations. They are naturally acquired under specific historical conditions by citizens. The form of land property has been transformed from ownership to land-use rights according to 'the Constitution' and 'the Law of Land Management.' Moreover, the basic Laws of our country and 'the Law of Urban Real Estate Administration' specify that there exist four kinds of right holders of real estate-the state (as a special civil entity), collectives, foreign investors, and citizens. They can all have their own real estate property and are equally regarded as civil subjects. Laws protect their legal rights and interests; they are empowered with the rights of 'possession, use, moneymaking, and disposal' with their real estate. 'Possession' has exclusivity. Either you or I can possess it. If I possess it, you cannot possess it, neither do other people or the danwei (work unit), including administrative departments and the state."

Competing interests

The author declares that he/she has no competing interests.

This paper is a modified edition of the author's doctoral dissertation "Civic Movement: The Power of Grass roots that Reshaped State-individual Relationships." The author appreciates the instruction at different stages provided by her Ph.D. advisor Professor Yi-yin Yang, and by M.A. advisor Professor Yuan Shen. This paper also benefited from discussions with Professor Stephen Reicher from University of St.Andrews and Lin Xiao and other colleagues in the "Youth Group" of the Institute of Sociology at the Chinese Academy of Social Sciences. The author also appreciates the financial support from the Youth Project of the National Social Sciences Fund for the project "The 'We-ness' construction-exemplified by rights defending groups" (project number: 08CSH022). The author is solely responsible for all content of this paper. 
Received: 20 June 2014 Accepted: 5 May 2015

Published online: 24 June 2015

\section{References}

Bi, Xiangyang. 2006. "From Roots to Citizens-a Survey Report of Contemporary Urbanization in B City" (in Chinese). Doctoral dissertation: Tsinghua University.

Burawoy, M. 2000. A sociology for the second great transformation? Annual Review of Sociology 26: 693-5.

Burawoy, M. 2006. Sociology and the Fate of Society. Beijing: Lecture at Tsinghua University.

Cao, Zhenghan. 2011. "China's Up-down Partition System of Governance and its Stability Mechanism" (in Chinese) Sociological Studies 1: 1-40.

Charles, Tilly, D McAdam, and S Tarrow. 2003. Contention and Democracy in Europe, 1650-2000". Cambridge: Cambridge University Press.

Goldman, Merle. 2005. From Comrade to Citizen: The Struggle for Political Rights in China. Cambridge, MA: Harvard University Press.

Liu, Zixi. 2010. "Incentives and Expansion—Legal and Social Relations Among Homeowners in B City" (in Chinese) Sociological Studies 5: 83-110.

O'Brien, Kevin J, and Lianjiang Li. 2006. Rightful Resistance in Rural China. Cambridge: Cambridge University Press.

Perry, Elizabeth. 2008. "Chinese-style Concept of Rights and Social Stability" (in Chinese). Translated by Xiaojun Yan. From the website of China Institute of Strategy and Management, sources: http://www.cssm.org.cn/ view.php?id=20510

Pieke, Frank. 2004. Contours of an anthropology of the Chinese state: political structure, agency and economic development in rural China. Journal of Royal Anthropological Institute 10(3): 517-38.

Sampson, E. 1988. The debate on individualism: Indigenous psychologies of the individual and their role in personal and societal functioning. American Psychologist 43(1): 15-22.

Shen, Yuan. 2007. Market, Class and Society — Key Issues in the Sociology of Transformation (in Chinese). Beijing: Social Sciences Academic Press.

Shi, Yunqing. 2007. "Create a Space for Protest" (in Chinese). Master's thesis: Tsinghua University.

Shi, Yunqing. 2012. "Citizens' Movements: Reshaping the State-Individual Relationships" (in Chinese). Chinese Academy of Social Sciences: Doctoral dissertation.

Touraine, Alain. 2008. The Return of Actors (Le Retour de L'Acteur). Translated by Shiwei Shu. Beijing: The Commercial Press.

Xiao, Lin. 2009. "The Land Value and Social Constraints-Exemplified by the Inner-city Renewal of Chongwen District, Beijing" (in Chinese). Doctoral dissertation: Tsinghua University.

Yan, Yunxiang. 2011. In The Self China: The Rise of Individuals in the Modern Chinese Society, edited by Meide He and Na Lu. Shanghai: Shanghai Translation Publishing House. "Introduction: Paradoxically Individual Image and Endless Disputes in the Process of Individualization" (in Chinese).

Yan, Yunxiang. 2012. "The Individualization of the Chinese Society" (in Chinese). Translated by Lu Yang et al. Shanghai: Shanghai Translation Publishing House.

Yang, Yiyin, and Zhang, Shuguang (eds.). 2008. Social psychology (in Chinese). Beijing: Capital University of Economics and Business Press.

Yang, Yiyin. 2008. "A preliminary measure of contemporary Chinese people's civic awareness" (in Chinese). Sociological Studies 2: 54-68.

Yang, Yiyin, C Manqi, C Wuqing, et al. 2010. Effects of boundary-permeated self and patriotism on social participation in Beijing Olympic games. Asian Journal of Social Psychology 13: 109-17.

Ying, Xing, and Jun Jin. 2000. The Special Issue of "Tsinghua Sociological Review.". Xiamen: Lujiang Press. "The Problematizing Process in Collective Petitions-A Story of Relocatees around a Southwest Hydroelectric Station" (in Chinese).

Ying, Xing. 2007. “The mobilization of Grassroots and expression mechanism of farmers' collective interests-a Comparative study with four cases" (in Chinese). Sociological Studies 2: 1-23.

Zhang, Taisu. 2009. "Why do Chinese people prefer petitions faced with administrative disputes?" in Chinese. Sociological Studies 3: 139-62.

Zhuang, WenJia. 2011. "Transcending the rights ascribed by the State? a case study of homeowners' protests in Guangzhou" (in Chinese). The Chinese Journal of Sociology 3: 88-113.

\section{Submit your manuscript to a SpringerOpen ${ }^{\circ}$ journal and benefit from:}

- Convenient online submission

- Rigorous peer review

- Immediate publication on acceptance

- Open access: articles freely available online

- High visibility within the field

Retaining the copyright to your article

Submit your next manuscript at $\boldsymbol{~ s p r i n g e r o p e n . c o m ~}$ 